\title{
Pertumbuhan dan Hasil Bawang Daun Akibat Perlakuan Pupuk Limbah Kulit Kopi dan Jarak Tanam
}

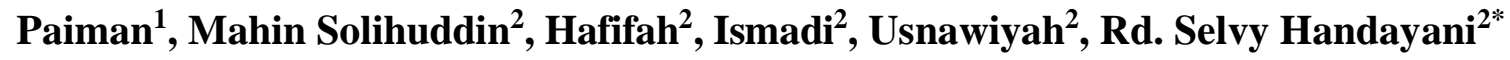 \\ ${ }^{1}$ Mahasiswa Program Magister Agroekoteknologi Fakultas Pertanian Universitas Malikussaleh, Aceh Utara \\ ${ }^{2}$ Program Studi Agroekoteknologi Fakultas Pertanian Universitas Malikussaleh, Aceh Utara \\ Kampus Unimal, Cot Teungku Nie Reuleut, Kecamatan Muara Batu, Kabupaten Aceh Utara, Indonesia \\ *Email korespondensi: selvy@unimal.ac.id
}

\begin{abstract}
ABSTRAK
Bawang daun adalah tanaman semusim yang memiliki nilai ekonomi yang tinggi. Petani sering mengandalkan pupuk kimia dalam membudidayakan komoditas ini, sehingga produksi bawang daun menjadi lebih kecil. Penelitian ini mencoba mengkaji penggunaan pupuk organik dengan memanfaatkan limbah kulit kopi untuk mengurangi penggunaan pupuk kimia. Jarak tanam yang sesuai merupakan salah satu upaya untuk meningkatkan produksi tanaman. Penelitian ini telah dilaksanakan di Gampong Ujung Gele, Kecamatan Bukit, Kabupaten Bener Meriah pada bulan Februari-Juli 2019. Percobaan dilakukan menggunakan Rancangan Acak Kelompok (RAK) dua faktor. Faktor pertama yaitu pupuk limbah kulit kopi menggunakan 4 taraf yaitu (P0) $0 \mathrm{~g} / \operatorname{tanaman},(\mathrm{P} 1) 60 \mathrm{~g} / \operatorname{tanaman},(\mathrm{P} 2) 90 \mathrm{~g} / \operatorname{tanaman}$, dan (P3) 120 g/tanaman. Faktor kedua yaitu jarak tanam yang menggunakan empat taraf yaitu (J1) $10 \mathrm{~cm} \mathrm{x} 20 \mathrm{~cm},(\mathrm{~J} 2)$ $15 \mathrm{~cm} \times 20 \mathrm{~cm}$ dan (J3) $20 \mathrm{~cm} \times 20 \mathrm{~cm}$. Pemberian pupuk tunggal berpengaruh terhadap semua variabel yang diamati, kecuali pertumbuhan tanaman dan hasil daun bawang. Pemberian pupuk $90 \mathrm{~g}$ per tanaman (P2) meningkatkan pertumbuhan dan hasil bawang hijau. Penerapan ruang tanam secara tunggal berpengaruh terhadap panjang akar, berat kering dan segar per rumpun, hasil per plot dan per hektar. Hasil penelitian menunjukkan bahwa jarak tanam terbaik yang diterapkan adalah $10 \mathrm{~cm}$ x $20 \mathrm{~cm}$ (J1). Terjadi interaksi antara pemberian pupuk kulit kopi dan jarak tanam terhadap jumlah anakan, jumlah daun dan panjang akar. Interaksi terbaik terdapat pada pemberian pupuk $90 \mathrm{~g} /$ tanaman dengan jarak tanam $10 \mathrm{~cm} \mathrm{x}$ $20 \mathrm{~cm}(\mathrm{P} 2 \mathrm{~J} 1)$.
\end{abstract}

Kata kunci: limbah, kulit kopi, jarak tanam

\section{ABSTRACT}

Green onion (Allium fistulosum L.) is an annual plant which cultivated for its high economic value. The farmers often rely on chemical fertilizer in growing this commodity, resulted in smaller production of green onions. This study has been tried to investigate the use of organic fertilizer by using cocoa peel waste to reduce the application of chemical fertilizer. The application of uniform planting space is one effort to enhance the production. This study was conducted in Ujung Gele Village, Bukit District, Bener Meriah Regency in February-July 2019, using Randomized Block Design (RBD) Factorial. The first factor was cocoa peel with 4 different doses : 0 g/plant (P0), 60 g/plant (P1), 90 g/plant (P2), and 120 g/plant (P3). The second factor was 3 different planting spaces: $10 \mathrm{~cm}$ x $20 \mathrm{~cm}(\mathrm{~J} 1), 15 \mathrm{~cm} \times 20 \mathrm{~cm}(\mathrm{~J} 2)$ and $20 \mathrm{~cm} \times 20$ $\mathrm{cm}(\mathrm{J} 3)$. The application of fertilizer alone has increased all the variables observed, except the plant growth and yield of green onions. The application of $90 \mathrm{~g}$ fertilizer per plant (P2) enhanced the growth and increased the yield of green onion. The application of planting space alone has improved root length, dry and fresh per clump, yield per plot and per hectare. The results showed that the best planting space applied was $10 \mathrm{~cm}$ x $20 \mathrm{~cm}(\mathrm{~J} 1)$. There was interaction between cocoa peel fertilizer and planting space on leaf number, tiller number and root length. The best interaction was demonstrated by the application of fertilizer $90 \mathrm{~g} /$ plant with planting space $10 \mathrm{~cm}$ x $20 \mathrm{~cm}(\mathrm{P} 2 \mathrm{~J} 1)$.

Keywords: waste, cocoa peel, planting space 


\section{PENDAHULUAN}

Bawang daun (Allium fistulosum L.) adalah tanaman sayuran daun semusim yang memiliki nilai ekonomi tinggi. Tanaman bawang daun banyak ditanam oleh petani di dataran tinggi (Saidah, 2012). Bawang daun biasanya digunakan sebagai bahan penyedap rasa (bumbu) dan bahan campuran sayuran lain pada beberapa jenis makanan populer di Indonesia, seperti soto, sup, campuran bumbu mi instan, dan penyedap jenis makanan lainnya. Tanaman bawang daun di Aceh Tengah merupakan tanaman sela yang dibudidayakan setelah fase musim kopi. Hal ini dilakukan untuk menyangga perekonomian para petani sampai tiba kembali musim kopi.

Produksi bawang daun di Indonesia tahun 2017 sebesar 573,216 ton dan mengalami peningkatan di tahun 2018 menjadi 590,596 ton (BPS, 2019). Data tersebut menunjukan terjadinya peningkatan produktivsi bawang daun dari tahun 2018 hingga 2019. Hal ini disebabkan pemasaran produksi bawang daun dalam kondisi segar tidak hanya untuk kebutuhan pasar dalam negeri (domestik) melainkan juga pasar luar negeri (ekspor).

Budidaya tanaman bawang daun yang dilakukan di kabupaten Aceh Tengah masih bergantung pada penggunaan pupuk kimia bersubsidi yang ketersediannya sangat terbatas guna mencukupi kebutuhan tanaman yang dibudidaya dalam skala luas. Penggunaan pupuk kimia juga dapat berdampak negatif bagi tanah. Oleh karena itu perlunya penggunaan bahan organik guna meningkatkan kesuburan, memperbaiki sifat fisik, biologi dan kimia tanah (Effendi et al., 2014). Salah satu jenis pupuk organik yang mudah didapatkan serta harganya murah adalah adalah pupuk kulit kopi.

Kopi termasuk tanaman yang menghasilkan limbah kulit yang cukup besar yakni berkisar 50-60\% dari hasil panen. Limbah kulit kopi biasanya dibuang dan belum dimanfaatkan secaranya optimal oleh petani meskipun dapat dijadikan sebagai pupuk kompos. Limbah kulit kopi mengandung nitrogen, fosfor, dan kalium yang cukup tinggi sehingga baik untuk pertumbuhan tanaman bawang daun.

Kulit buah kopi memilki kadar C-organik 45,3\%, kadar nitrogen $2,98 \%$, fosfor $0,18 \%$ dan kalium 2,26\% (Ditjenbun, 2006). Hal ini menunjukkan bahwa kulit buah kopi sangat potensial untuk pakan ternak ruminansia misalnya kambing, sapid an sebagainya. Kulit buah kopi juga mengandung zat nutrisimisalnya protein kasar $10,4 \%$, serat kasar $17,2 \%$ dan energi metabolis $14,34 \mathrm{MJ} / \mathrm{kg}$ yang relatif sama dengan zat nutrisi rumput. Limbah kulit kopi mengandung protein kasar sebesar 10,4 \%, yang hampir sama dengan jumlah protein yang terdapat pada bekatul dan kandungan energi metabolismenya sebesar $3.356 \mathrm{kkal} / \mathrm{kg}$ (Zainuddin \& Murtisari, 1995). Pemberian kompos kulit kopi $90 \mathrm{~g} /$ tanaman mampu meningkatkan jumlah daun hingga 24,96\%, diameter umbi $29,59 \%$, produksi per plot $50 \%$ pada tanaman bawang merah (Sahputra et al., 2013). Di samping penggunaan pupuk limbah kopi, kebersilan budidaya tanaman bawang daun juga dipengaruhi oleh jarak tanam yang tepat.

Penggunaan jarak tanam yang teratur adalah satu usaha yang dapat dilakukan untuk meningkatkan produksi bawang daun secara maksimal. Hasil penelitian Lestari, (2016) menyatakan bahwa penggunaan jarak tanam $20 \mathrm{x}$ $20 \mathrm{~cm}$ dapat menyebabkan peningkatan jumlah anakan per rumpun jumlah daun per rumpun, bobot basah per rumpun, bobot kering brangkasan dan hasil tanaman per hektar. Tujuan penelitian ini adalah untuk mengetahui pengaruh pemberian pupuk organik limbah kulit kopi dan untuk mengetahui pengaruh pengaturan jarak tanam terhadap pertumbuhan dan hasil tanaman bawang daun.

\section{METODE PENELITIAN}

Penelitan dilaksanakan di Desa Ujung Gele, Kecamatan Bukit, Kabupaten Bener Meriah, Aceh dan Laboratorium Ilmu-ilmu Dasar Fakultas Pertanian Universitas Malikussaleh. Penelitian ini dilaksanakan pada bulan Februari sampai Juli 2019.

Bahan yang digunakan dalam penelitian ini adalah bibit daun bawang varietas lokal, pupuk kompos limbah kulit kopi, plastik mulsa, insektisida dan fungisida. Sedangkan alat yang digunakan adalah traktor, cangkul, garu, pisau kater, gembor, timbangan analitik, sprayer, papan nama pengamatan, kamera, dan alat tulis.

Penelitian ini dilakukan dengan metode Rancangan Acak Kelompok (RAK) pola faktorial dimana perlakuan yang diuji terdiri atas dua faktor. Faktor pertama adalah dosis pupuk kompos kulit kopi yang terdiri atas empat taraf $\mathrm{P} 0=0 \mathrm{~g} /$ tanaman, $\mathrm{P} 1=60 \mathrm{~g} /$ tanaman, $\mathrm{P} 2=90 \mathrm{~g} /$ tanaman, dan $\mathrm{P} 3=120$ $\mathrm{g} /$ tanaman. Faktor kedua adalah jarak tanam dengan tiga taraf, yaitu $\mathrm{J} 1=10 \mathrm{~cm} \times 20 \mathrm{~cm}, \mathrm{~J} 2=$ $15 \mathrm{~cm} \times 20 \mathrm{~cm}$, dan $\mathrm{J} 3=20 \mathrm{~cm} \times 20 \mathrm{~cm}$. Dengan demikian penelitian ini terdiri atas 12 kombinasi perlakuan dengan tiga ulangan, sehingga terdapat 36 unit percobaan. 
Bibit bawang daun yang digunakan adalah hasil perbanyakan vegetatif yaitu dengan memisahkan anakan. Sumber bibit tanaman bawang daun dipilih dari tanaman yang telah berumur dua bulan setelah tanam dan tidak terserang hama ataupun penyakit. Pemisahan rumpun induk dilakukan sebagai bakal bibit. Setiap bagian terdiri dari satu batang tanaman (anakan) yang kemudian sebagian daunnya dipotong.

Lahan diolah satu kali dengan menggunakan tractor sedalam 20-30 cm. Bedengan dibentuk dengan menggunakan cangkul. Ukuran petak percobaan adalah $80 \times 80$ $\mathrm{cm}$, antar bedengan berjarak $50 \mathrm{~cm}$, dan antar blok berjarak $100 \mathrm{~cm}$.

Mulsa dipasang setelah lahan selesai diolah dan bedengan sudah selesai dibuat. Mulsa yang digunakan adalah mulsa plastik hitam perak (MPHP). MPHP dipasang dengan cara ditarik ujung-ujungnya secara bersamaan lalu bagian ujung mulsa dipasak dengan menggunakan bambu. Lubang tanam pada mulsa dilubangi menggunakan kaleng susu bekar yang dipanaskan dengan api.

Penanaman bawang daun dilakukan di lubang tanam pada petak percobaan. Penanaman dilakukan pada pagi hari dan setiap lubang tanam ditanaman satu bibit tanaman. Lubang tanam sedalam $5 \mathrm{~cm}$ dibuat dengan menggunakan. Bibit tanaman bawang daun ditanam sesaui dengan perlakuan yaitu $10 \times 20 \mathrm{~cm}$ (32 tanaman/petak), $15 \times 20 \mathrm{~cm}$ (24 tanaman/petak) dan $20 \times 20 \mathrm{~cm}$ (16 tanaman/petak).

Pupuk kompos kulit kopi diberikan sebelum MPHP dipasang yang ditebar pada permukaan setiap bedeng percobaan. Pemberian pupuk kompos kulit kopi dilakukan seminggu sebelum tanaman bawang daun ditanam. Dosiskompos kulit kopi perlakuan diberikan sebanyak 0 g/tanaman, $60 \mathrm{~g} / \mathrm{tanaman}, \quad 90$ $\mathrm{g} /$ tanaman, dan $120 \mathrm{~g} /$ tanaman.

Pemanenan dilakukan pada umur 60 hari setelah tanam. Bawang daun yang siap dipanen ditandai dengan menguningnya beberapa helai daun bagian bawah atau mengering. Pemanenan dilakukan dengan cara mencabut seluruh bagian tanaman sampai akar. Tanah yang menempel pada akar dibersihkan dengan cara memasukan akar tanaman kedalam air. Pengamatan dilakukan selama delapan minggu. Peubah yang diamati meliputi bagian vegetatif dan generatif tanaman.

Data percobaan hasil pengamatan dianalisis statistik menggunakan analisis ragam. Apabila hasil uji F menyatakan adanya pengaruh yang nyata antar perlakuan, maka dilakukan analisis lanjut dengan Uji DMRT (Duncan's Multiple Range Test) pada taraf 5\%. Analisis data dilakukan dengan menggunakan software SAS v9.13 portable.

\section{HASIL DAN PEMBAHASAN}

\section{Hasil}

Berdasarkan Tabel 1 terlihat bahwa perlakuan tunggal pupuk limbah kulit kopi tidak menunjukan pengaruh terhadap tinggi tanaman bawang daun. Akan tetapi pemberian pupuk limbah kulit kopi $120 \mathrm{~g}$ (P3) secara rataan memberikan nilai tertinggi. Perlakuan jarak tanam secara tunggal tidak menunjukan pengaruh pada peubah tinggi tanaman. Akan tetapi perlakuan jarak tanam $10 \mathrm{x}$ $20 \mathrm{~cm}$ (J1) memberikan nilai rataan tertinggi.

Berdasarkan hasil analisis ragam terdapat pengaruh antara kombinasi perlakuan pupuk kulit kopi dan jarak tanam terhadap jumlah daun tanaman bawang daun pada umur 3, 4 dan 5 MST.Data hasil uji lanjut jumlah daun tanaman bawang daun dengan mengunakan DMRT taraf 5\% ditampilkan padaTabel 2.

Berdasarkan Tabel 2 terlihat bahwa perlakuan kombinasi pupuk limbah kulit kopi dan jarak tanam menunjukan pengaruh terhadap jumlah daun. Kombinasi perlakuan pupuk limbah kulit kopi dan jarak tanam P1J1pada 3 MST memberikan jumlah daun terbanyak yaitu 4,46 helai, sedangkan perlakuan kombinasi P2J3 memberikan jumlah daun terendah yaitu 3,33 helai. Kombinasi perlakuan pemberian pupuk kulit kopi dan jarak tanam P3J3 pada 4 MST memberikan jumlah daun paling banyak yaitu 6,50 helai, sedangkan perlakuan P0J2 memberikan jumlah daun paling rendah yaitu 4,39 helai. Kombinasi perlakuan pupuk limbah kulit kopi dan jarak tanam P3J3 pada 5 MST memberikan jumlah daun paling banyak yaitu 7,91 helai, sedangkan perlakuan P0J2 memberikan jumlah daun paling rendah yaitu 4,94 helai.

Berdasarkan Tabel 3 diketahui bahwa perlakuan tunggal pupuk limbah kulit kopi berpengaruh terhadap jumlah daun pada umur 4 dan 5 MST. Pemberian pupuk limbah kulit limbah kopi $60 \mathrm{~g}(\mathrm{P} 1)$ pada 4 MST memberikan jumlah daunterbanyak.Pemberian pupuk kulit kopi $120 \mathrm{~g}$ (P3) pada 5 MST memberikan jumlah daun paling banyak dibandingkan perlakuan lainnya. Perlakuan jarak tanam secara tunggal tidak menunjukan pengaruh pada peubah jumlah daun tanaman bawang daun. 
Hasil analisis ragam menunjukkan kombinasi perlakuan antara pemberian pupuk kulit kopi dan jarak tanam terhadap jumlah anakan bawang daun pada umur 3, 4 dan 5 MST. Perlakuan tunggal pemberian pupuk limbah kulit kopi secara tunggal juga menunjukkan pengaruh pada peubah jumlah anakan. Data hasil uji lanjut jumlah anakan tanaman bawang daun dengan mengunakan DMRT taraf 5\% dapat dilihat pada Tabel 4 dan 5.

Berdasarkan Tabel 4 dapat dilihat bahwa kombinasi perlakuan pupuk kulit kopi dan jarak tanam menunjukan pengaruh terhadap jumlah anakan. kombinasi perlakuan pupuk kulit kopi $120 \mathrm{~g} /$ tanaman dan jarak tanam 20 x 20cm (P3J3) memberikan jumlah anakan tertinggi pada umur 3, 4 dan 5 MST.

Tabel 5 menunjukkan bahwa perlakuan tunggal pupuk kulit kopi berpengaruh terhadap jumlah anakan tanaman pada 2 dan 3 MST. Pemberian pupuk kulit kopi limbah kopi $60 \mathrm{~g}$ (P1) memberikan jumlah anakan paling banyak dibandingkan perlakuan lainnya. Perlakuan jarak tanam secara tunggal tidak menunjukan pengaruh pada jumlah anakan tanaman bawang daun.

Berdasarkan hasil analisis ragam menunjukkan bahwa kombinasi perlakuan pupuk kulit kopi dan jarak tanam tidak berpengaruh terhadap peubah panjang dan volume akar tanaman bawang daun. Perlakuan tunggal pemberian pupuk limbah kulit kopi dan jarak tanam menunjukkan pengaruh pada peubah panjang dan volume akar. Data hasil uji lanjut panjang dan volume akar tanaman bawang daun dengan mengunakan DMRT taraf 5\% dapat disajikan pada Tabel 6.

Pada Tabel 6 dapat dilihat bahwa perlakuan tunggal pemberian pupuk limbah kulit kopi menunjukan pengaruh pada panjang dan volume akartanaman bawang daun. Pemberian pupuk limbah kulit kopi dapat meningkatkan panjang akar, sedangkan pada volume akar pemberian pupuk limbah kulit kopi 90 dan 12 g/tanaman menyebabkan peningkatan volume akar. Perlakuan jarak tanam hanya menunjukan pengaruh terhadap panjang akar. Panjang akar tertinggi terdapat pada Jarak tanam $20 \times 20 \mathrm{~cm}$ (J3), akan tetapi secara statistik tidak ada perbedaan dengan jarak tanam 15 x $20 \mathrm{~cm}$ (J2).

Hasil analisis ragam menunjukan bahwa kombinasi perlakuan pupuk limbah kulit kopi dan jarak tanam tidak menunjukkan pengaruh terhadap berat per rumpun, hasil per plot, berat brangkasan kering per rumpun, dan hasil per ha tanaman bawang daun. Data uji lanjut pada peubah berat bawang daun per rumpun dengan menggunakan DMRT taraf 5\% dapat dilihat pada Tabel 7.

Berdasarkan Tabel 7 dapat dilihat bahwa perlakuan tunggal pemberian pupuk limbah kulit kopi menunjukan pengaruh berat per rumpun, hasil per plot, berat brangkasan kering per rumpun, dan hasil per Ha tanaman bawang daun. Pemberian pupuk limbah kulit kopi 120 g (P3) memberikan hasil terbaik dibandingkan perlakuan lainnya.

\section{Pembahasan}

Hasil penelitian menunjukkan bahwa faktor kombinasi perlakuan antara pemberian pupuk limbah kulit kopi dan jarak tanam berpengaruh pada peubah jumlah daun dan jumlah anakan.Secara keseluruhan perlakuan P3J3 (dosis pupuk limbah kulit kopi 120g/tanaman pada jarak tanam 20 x 20cm menunjukkan perlakuan terbaik.

Perlakuan tunggal pupuk limbah kulit kopi memberikan pengaruh pada peubah jumlah daun 4 dan 5 MST, jumlah anakan 2 dan 3 MST, panjang dan volume akar, berat per rumpun, hasil per plot, berat brangkasan kering per rumpun, dan hasil per ha. Perlakuan pupuk limbah kulit kopi 120 $\mathrm{g} /$ tanaman memberikan hasil terbaik.

Pertumbuhan dan hasil (produksi) tanaman bawang daun akan meningkat dengan dilakukannya aplikasi pupuk yang optimal. Pemupukan berfungsi untuk menambah unsur hara yang tersedia di dalam tanah. Kandungan unsur hara nitrogen $(\mathrm{N})$ kulit kopi yang tinggi sangat sesuai untuk pertumbuhan tanaman bawang daun yang memang membutuhkan unsur hara nitrogen (Novizan, 2002). Budidaya tanaman bawang daun memerlukan unsur nitrogen yang lebih banyak, karena termasuk dalam sayuran yang dikonsumsi daunnya.

Tanaman membutuhkan unsur nitrogen agar dapat meningkatkan pertumbuhan vegetatif tanaman. Selain itu unsur N dapat meningkatkan kadar protein, untuk perkembangbiakan mikroorganisme dalam tanah, mensintesa asam amino juga protein di dalam tanaman serta dapat meningkatkan produksi tanaman penghasil dedaunan (Novizan, 2002).

Perlakuan tunggal jarak tanam menunjukan pengaruh terhadap panjang dan volume akar, berat per rumpun, hasil per plot, berat brangkasan kering per rumpun, dan hasil per ha. Jarak tanam yang lebih rapat menghasilkan tanaman bawang daun yang lebih lebih banyak namun lebih kecil memanjang dibandingkan dengan tanaman pada jarak tanam lebih renggang. Untuk keperluan pasar yang dibutuhkan masyarakat sekitar yang diperlukan adalah bawang daun yang lebih panjang namun secara 
keseluruhan per plot atau per hektar lebih berat karena untuk luasan yang sama dapat ditanam lebih banyak bibit bawang daun. Oleh karena itu jarak tanam J1 $(10 \times 20 \mathrm{~cm})$ memberikan hasil terbaik sesuai kebutuhan konsumen.

Perlakuan jarak tanam yang lebih rapat yaitu pada perlakuan $\mathrm{J} 1 \quad\left(\begin{array}{lllll}10 & \mathrm{x} & 20 & \mathrm{~cm}\end{array}\right)$ menyebabkan tanaman bawang daun menjadi lebih kecil memanjang namun jumlahnya lebih banyak. Jarak tanam yang lebih rapat menyebabkan terjadi kompetisi cahaya matahari. Hal ini dapat memacu pertumbuhan tinggi bawang daun untuk mendapatkan cahaya (efek etiolasi). Pertambahan tinggi tanaman akan menyebabkan jumlah daun menjadi lebih sedikit. Hal ini disebabkan karena hasil fotosintesis lebih banyak digunakan untuk pertumbuhan tinggi tanaman. Batang tanaman menjadi lebih kecil dan seringkali lebih tinggi dapat disebabkan oleh peningkatan kerapatan tanaman (Gardner et al., 2008). Organ tanaman seperti akar, batang dan daun merupakan daerah pemanfaatan hasil asimilasi (fotosintesis) sepanjang masa pertumbuhan vegetatif.

Batang tanaman bawang daun yang ditanam pada jarak tanam lebih renggang lebih besar, namun karena jumlah bibit lebih sedikit, maka hasil per plot lebih rendah. Hasil penelitian (Fera, et al., 2019), menyatakan bahwa jarak tanam bawang daun $20 \times 20 \mathrm{~cm}$ pada penelitian Fera, et al (2009) memperlihatkan kecenderungan respon pertumbuhan dan hasil yang lebih baik. Hal ini terlihat pada peubah luas daun, bobot segar, dan bobot kering tanaman. Kompetisi tanaman untuk mendapatkan unsur hara, air dan sinar matahari pada jarak tanam $20 \times 20 \mathrm{~cm}$ lebih rendah dibandingkan dengan jarak tanam lebih rapat, sehingga pemanfaatan unsur hara lebih banyak digunakan untuk proses metabolisme yang akan berdampak pada penambahan luas daun dan bobot segar. Pada jarak tanam renggang menghasilkan jumlah populasi tanaman lebih sedikit dibandingkan dengan jarak tanam sempit. Populasi tanaman dengan jumlah yang banyak serta pemberian pemupukan yang optimal pada kondisi lingkungan yang baik menghasilkan produksi tanaman bawang daun yang maksimal.

Kepadatan tanaman sangat berhubungan erat dengan hasil tanaman. Hal ini karena peningkatan jumlah populasi tanaman akan menyebabkan peningkatan berat kering total tanaman dan indeks luas daun (ILD) (Gardner et al., 2008). Bukaan vegetasi akan menyediakan ruang kosong yang kemudian akan diinvasi oleh berbagai jenis tumbuhan pengganggu yang memiliki pertumbuhan sangat cepat. Sifat mendominasi suatu spesies gulma tertentu dapat menimbulkan dampak buruk bagi ekosistem yang dapat menurunkan hasil tanaman

\section{KESIMPULAN}

1. Perlakuan tunggal pemberian pupuk (P) berpengaruh terhadap pertumbuhan dan hasil tanaman bawang daun. Hal ini terlihat pada peubah jumlah daun 4 dan 5 MST, jumlah anakan 2 dan 5 MST, panjang akar, volume akar, berat per rumpun, berat brangkasan per rumpun, hasil per plot dan hasil per hektar. Perlakuan terbaik adalah dengan dosis pupuk (P2) yaitu $90 \mathrm{~g} /$ tanaman.

2. Perlakuan jarak tanam tunggal berpengaruh terhadap peubah panjang akar, berat per rumpun, berat kering brangkasanper rumpun, hasil tanaman per plot dan hasil tanaman perhektar saat panen bawang daun dan tidak berpengaruh terhadap tinggi tanaman, jumlah daun, jumlah anakan dan volume akar. Perlakuan terbaik adalah dengan jarak tanam J1 $(10 \times 20 \mathrm{~cm})$.

3. Terdapat interaksi antara kombinasi perlakuan pupuk limbah kulit kopi dan jarak tanam pada peubah jumlah daun 3, 4 dan 5 MST, jumlah anakan 3, 4 dan 5 MST dan panjang akar. Perlakuan terbaik adalah (P2J1) pemberian pupuk limbah kulit kopi yang diberi pupuk limbah kulit kopi 90 g/tanaman.

\section{DAFTAR PUSTAKA}

Badan Pusat Statistik. 2019. Statistik Produksi Hortikultura. Kementrian Pertanian. Direktorat Jendral Hortikultura. Jakarta.

Ditjenbun, 2006. Pedoman Pemanfaatan Limbah dari Pembukaan Lahan. Direktorat Jenderal Perkebunan. Departemen Pertanian.

Effendi, D., Sufardi dan Muyassir. 2014. Aplikasi Biochar Dan Kompos Kulit Kopi Untuk Meningkatkan Hasil Kentang Pada Andisol Atu Lintang Kabupaten Aceh Tengah. Jurnal Manajemen Sumberdaya Lahan 3(2), 452-458.

Fera A.R., SumartonoG. H., Tini E.W. 2019. Pertumbuhan dan Hasil Tanaman Bawang Daun (Allium fistulosum L.) pada Jarak Tanam dan Pemotongan Bibit Yang Berbeda. Jurnal Penelitian Pertanian Terapan 19(1), 11-18.

Gardner FP, Pearce RB, Mitchell RL. 2008. Fisiologi Tanaman Budidaya (Terjemahan oleh Herawati Susilo). UI Press, Jakarta. 
Lestari, R. 2016. Respons Tanaman Bawang Daun (Allium fistulosum L.) Terhadap Aplikasi Pupuk Daun Pada Berbagai Jarak Tanam (Skripsi) Lampung: Sekolah Tinggi Ilmu Pertanian (Stiper) Dharma Wacana Metro.

Novizan, 2002.Petunjuk Pemupukan yang Efektif. Agro Medya Pustaka.

Sahputra, A. Barus, A dan Sipayung, S. 2013.Pertumbuhan dan Produksi Bawang Merah (Allium ascalonicum L.) Terhadap Pemberian Kompos Pupuk Organik Cair. Jurnal Online Agroekoteknologi 2(1), 2635 .
Saidah, 2012. Teknik Budidaya Sayuran Dataran Tinggi. Jawa Barat.

Zainuddin, D. dan T. Murtisari. 1995. Penggunaan limbah agro-industri buah kopi (kulit buah kopi) dalam ransum ayam pedaging (Broiler). Pros. Pertemuan IImiah Komunikasi dan Penyaluran Hasil Penelitian. Semarang: Sub Balai Penelitian Klepu, Puslitbang Petemakan, Badan Litbang Pertanian, 71-78. 